\title{
Resilience in intentionally destroyed historic settlements: An examination on Kirkuk Citadel and the old town of Van
}

\author{
F. Duygu Saban*a ${ }^{*}$ \\ Mustafa Mokhtar ${ }^{\mathrm{b}}$ (D) \\ Tuba Akar' ${ }^{\mathrm{B}}$
}

\begin{abstract}
Armed conflict is considered a major risk for cultural heritage since the Second World War and guidelines are prepared by international organizations such as UNESCO and ICCROM on risk management and protection of cultural heritage in conflict-affected areas. However, the main concerns are reducing risks prior to the armed conflict by identifying, analyzing, evaluating, treating and monitoring risks and managing them before the risk occurs. The literature is quite narrow in respect to the ways of protecting cultural heritage and sustaining life for both buildings and people in intentionally destroyed historic settlements. Within this context, this study aims to raise the question on how to manage change in the intentionally destroyed historic settlements and how to strengthen resilience in conflict-affected areas. In order to achieve this aim, an examination on two case studies, Kirkuk Citadel and the Old Town of Van, which were both intentionally destroyed as a result of armed conflict is made using comparative analysis method. The cases are chosen to represent different time periods, scales and types of destruction. Depending on the international law and guidelines, the study tries to understand the impact of armed conflict on the historic settlements embracing tangible and intangible cultural heritage, types of risks that threaten them and the ways to strengthen resilience in such areas. It is revealed as a result of the study that for both case study areas, being in the tentative list of UNESCO World Heritage is seen a primary step to be internationally recognized and to claim help for future actions aiming to reduce risks. Nevertheless, it can be argued that strategies have to be developed depending on the size and level of destruction, and the level of intervention to preserve and to rehabilitate life in such historic settlements, as each intentionally destroyed historic settlement has unique cultural, political and economic characteristics.
\end{abstract}




\section{Introduction}

Armed conflict and the protection of cultural heritage against hazards thereof constitutes a worldwide problem since the end of the 19th century, which has been treated in a large scale since the Second World War, however destruction of cultural heritage in former Yugoslavia, Syria, Mali and Iraq in the last decades raised new discussions. Starting with the Declaration of Paris in 1856, an international consensus on the conduct of war has been tried to be established (Higgins, 1909). One of the earliest texts stating regulations concerning the treatment to cultural heritage during war is the First Hague Convention, dated 1899, determining in Article 27 that "In sieges and bombardments all necessary steps should be taken to spare as far as possible edifices devoted to religion, art, science, and charity, hospitals, and places where the sick and wounded are collected, provided they are not used at the same time for military purposes" (Brown Scott, 1920, p. 257). Keane (2004, pp. 6-7) claims that the following 1907 Hague Regulations concerning the Laws and Customs of War on Land expanded the legal protection of cultural heritage, included the term historic monuments to Article 27 and that International Military Tribunal Sitting in Nuremberg, Germany in 1945-1946 marked the beginning of the customary protection of cultural property. The failure of protecting cultural properties in Europe during the First and the Second World Wars, despite The Hague Regulations, resulted in organizing a special convention for the protection of cultural property in the event of armed conflict in Hague. The 1954 Hague Convention1 (Url-1) recognizes that cultural property has suffered grave damage during recent armed conflicts and that, by reason of the developments in the technique of warfare, it is in increasing danger of destruction, and states that damage to cultural property belonging to any people whatsoever means damage to the cultural heritage of all mankind, since each people makes its contribution to the culture of the world and that cultural heritage should receive international protection.

In Article 9 of the 1954 Hague Convention, it is declared that the High Contracting Parties should ensure the immunity of cultural property under special protection which is listed in the International Register. In the Register list dated 2015, it can be seen that only Germany, Mexico, The Netherlands and Vatican City State have their cultural heritage registered (Url-2). The reason behind this fact lies in the 5th paragraph of Article 8 of the text, which is "If any cultural property ... is situated near an important military objective ..., it may nevertheless be placed under special protection if the High Contracting Party asking for that protection undertakes, in the event of armed conflict, to make no use of the objective...". Keane (2004, pp. 16-17) argues that this is one of the major shortcomings to the system of special protection and the other is that States may object to a proposal for entry into the International Register, which resulted in rejecting the inclusion of Angor Wat complex into the list depending on the grounds that four States did not recognize the legitimacy of the Cambodian government.

Despite the shortcomings of the text developed as a result of The Hague Peace Conference in 1954 , it is clear that consideration of cultural heritage as a product of the contribution each people makes and that should belong to all mankind has been the main motive for cultural heritage protection. Since then UNESCO has the central role in relation to both the development of the 1954 Hague Convention and to strengthen it, which has engendered World Heritage Convention in 1972 (Boylan, 1993, p. 127). Boylan (1993) emphasized UNESCO's role in decisively implementing regulations stated in 1954 Hague Convention, increasing the number of High Contracting Parties and to constitute effective national and international measures for protecting cultural heritage. Depending on Boylan's report and discussions undertaken (Chadra, 2001), the Second Protocol to The Hague Convention of 1954 for the Protection of Cultural Property in the Event of Armed Conflicts was adopted in 1999. The Second Protocol mainly simplified the procedure for the grant of special protection and introduced 'enhanced protection', tightened the concept of military necessity, and established individual criminal responsibility and an institutional mechanism to promote respect for cultural property and monitor its implementation. Article 10 of the Protocol

${ }^{1}$ For detailed analysis of the 1954 Hague Convention see Schipper, F. T. and Frank, E. (2013). 
declares that three conditions should be met to be placed under enhanced protection; being of the greatest importance for humanity, being protected by adequate domestic legal and administrative measures and not being used for military purposes or to shield military sites. The Protocol also expands the coverage by stating that it shall apply in the event of an armed conflict not of an international character, occurring within the territory of one of the Parties in Article 22.

These efforts however arguably have been relatively effective in protecting cultural heritage. UNESCO, with the help of bodies such as ICOMOS and ICCROM has been the leading authority to identify heritage properties for protection, by way of introducing World Heritage List. The list does not necessarily include cultural heritage under threat of an armed conflict but establishes a worldwide knowledge of valuable heritage properties belonging to all mankind, and therefore UNESCO also has the responsibility for introducing measures to protect them. Lostal $(2017$, p. 35) argues that the 1999 Second Protocol Committee aimed to examine the synergies between enhanced protection and world cultural heritage in order to revamp the enhanced protection regime of the protocol, as there were more than eight hundred cultural sites on the UNESCO World Heritage List at the time of the preparation of the Protocol. Nevertheless, UNESCO aiming to keep guiding to the States and related bodies that desire to keep their cultural heritage safe, bring about new topics for discussion, trace developments in the world and develop and publish new declarations such as UNESCO Declaration Concerning the Intentional Destruction of Cultural Heritage in 2003, Managing Disaster Risks for World Heritage in 2010, and so on.

The 2003 UNESCO Declaration Concerning the Intentional Destruction of Cultural Heritage states that the international community recognizes the importance of the protection of cultural heritage and reaffirms its commitment to fight against its intentional destruction in any form so that such cultural heritage may be transmitted to the succeeding generations, and defines intentional destruction as "an act intended to destroy in whole or in part cultural heritage, thus compromising its integrity, in a manner which constitutes a violation of international law or an unjustifiable offence to the principles of humanity and dictates of public conscience" (UNESCO, 2003, p. 448). The Declaration gives responsibility to the States both to take measures to prohibit, prevent, stop and punish any intentional destruction of cultural heritage within the extent provided for by international law, and also to establish jurisdiction over and provide effective criminal sanctions against individuals who commit or order to be committed acts of intentional destruction. Nevertheless, the intentional destruction that was practiced before the 2003 Declaration endangered the integrity of cultural heritage in various parts of the world. Therefore, one of the major problems concerning the intentional destruction against cultural heritage is the type of strategy to be developed in order to both regain the integrity of the heritage areas and also to make sure that the States and relevant bodies would be prepared for possible risks in the future.

\subsection{Armed Conflict and Cultural Heritage}

Threats to cultural heritage in the event of armed conflict are argued to result from intentional destruction, collateral damage, forced neglect, as well as from the organized looting and illicit trafficking of cultural objects (UNESCO, 2015, pp. 1-5). UNESCO (2015, pp. 1-6) defines the combination of the intentional and systematic destruction of cultural heritage, the denial of cultural identity, including books and manuscripts, traditional practices, as well as places of worship, and of memory and learning as "cultural cleansing". There is argued to be a widespread tendency towards considering cultural heritage less important while people's lives are at stake. However, it was suggested in 2016 referring to the armed conflict in the Middle East and Asia that "The fight to protect the peoples of the region and their heritage cannot be separated" 2 . Therefore, the idea of considering cultural cleansing and mass atrocities as intertwined concepts are getting more supporters every day and suggestions are made for future actions to both protect cultural heritage and also to sustain cultural continuity (Weiss and Connelly, 2017, pp. 44-45).

${ }^{2}$ Middle East Institute, Asia Society, and the Antiquities Coalition (2016) 
Nevertheless, it is revealed as a result of the literature review that all efforts are focusing on identifying risks that cultural heritage is facing during armed conflict, trying to prevent them or plan treatment methods before an armed conflict, manage change and threats during an armed conflict, and to manage the whole process with the inclusion of all related bodies in an international environment. Therefore, the success of the process arguably depends on the intention of the Party States, and whether they are willing to cooperate with UNESCO and other authorized bodies that can supply expert intervention. It is clear that there are other major issues that have to be taken into account considering the unexpected scale of destruction of heritage sites, which might result in the extinction of life and cultural heritage. Within this context, this study aims to raise the questions on how to manage change in the intentionally destroyed historic settlements and how to strengthen resilience in conflict-affected areas.

\section{Method}

Depending on the international law and guidelines, the study tries to understand the impact of armed conflict on the historic settlements embracing tangible and intangible cultural heritage, types of risks that threaten them and the ways to strengthen resilience in such areas. In order to achieve the aims mentioned above, an examination on two case studies, Kirkuk Citadel and the Old Town of Van, which were both intentionally destroyed as a result of armed conflict is made using comparative analysis method. The cases are chosen to represent different time periods, scales and types of destruction, and both were destroyed as a result of internal armed conflicts. While the Old Town of Van was burnt down in 1915 by the Armenian citizens, Kirkuk Citadel was destroyed in 1998 aiming to force Turkmen (Turcoman) community living in the area to move out.

The examination is undertaken following the scientific methodology introduced by ICCROM in 2016 which was directed to the cultural heritage professionals and institutions in the Middle East region for risk examination and assessment.

\section{Resilience to Disasters and Risk Management}

Resilience is defined as "the ability of a system and its component parts to anticipate, absorb, accommodate, or recover from the effects of a hazardous event in a timely and efficient manner, including through ensuring the preservation, restoration, or improvement of its essential basic structures and functions" (IPCC, 2012, p. 5). It is argued that resilience could apply to both people and the built and natural environment and is shaped by both physical and social factors (Murthy, 2013 , p. 21). Concerning the role of cultural heritage, it is widely accepted that the intrinsic historic or artistic value, fundamental spiritual and psycho-social support and the sense of belonging it provides to communities during the disaster recovery phase make cultural heritage an important aspect and that its protection should be promoted for a robust culture of resilience in heritage sites.

Murthy $(2013$, p. 30$)$ accepting that cultural heritage includes knowledge, beliefs, values and behaviours that give communities their unique identities, emphasizes the role of cultural heritage in promoting resilience to disasters focusing on two aspects, the role of traditional knowledge in building resilience and the role of culture in mobilizing actions that reduce disaster risk and support disaster recovery. Therefore, it is possible to argue that despite international legislation and set of guidance provided by UNESCO and other relevant bodies, there is a need for understanding the cultural codes, beliefs, values and behaviours at the local level in order to develop successful strategies for providing resilience to disasters.

Nevertheless, it is widely accepted that the first step for ensuring resilience to disasters is to understand the context and identify the risks threatening cultural heritage and heritage sites in general. Risk, is defined as 'the chance of something happening that will have a negative impact on our objectives' (ICCROM, 2016, p. 9). Applying the definition to the cultural heritage, risk management would advise a methodology to preserve the existing cultural heritage from the expected loss of value to the heritage assets (ICCROM, 2016, p.10). It is the process of 
understanding and dealing with possible negative impacts on the cultural objectives, including identification, analysis, and evaluation of risks. Followed by application of an action to 'treat' risks, avoiding and eliminating or reducing the risks that are considered unacceptable. Also, it is important to mention that risk management is a continuous process, to ensure that negative impacts on cultural objectives will be minimized by continuous monitoring of the risks and adjusting the actions to it accordingly (ICCROM, 2016; p. 14).

ICCROM Guidance (2016, p. 20) aiming to understand all aspects of the context in which the heritage asset is situated, identified political environment, actors and stakeholders, administrative and operational aspects, financial context, legal aspects, physical environment and socio-cultural environment as the major topics that should be examined. And also defined 10 agents that can cause deterioration and loss to heritage assets as physical forces, dissociation, incorrect Relative Humidity, incorrect temperature, light and UV, pollutants, pests, water, fire and criminals (ICCROM, 2016, p. 27). Within the scope of this study, the chosen case studies and their current situation are examined in accordance with the aforementioned guidance in order to develop an understanding of the general context of intentionally destroyed historic settlements and to identify risks they are facing to discuss challenges that face them and suggest ways to promote resilience in such areas.

\subsection{The Case of Kirkuk Citadel}

Kirkuk City has a multi-ethnic society consisting of three major ethnicities, the Kurds, Arabs and Turkmens, as well as several other ethnic groups. Given to both geopolitical, social and economic status of Kirkuk City, and the continuing ethnical conflict during the last decades, between different local political parties over the ownership of the City, the cultural heritage and especially Kirkuk Citadel experienced severe deterioration. In the year 1998, the Iraqi regime (Saddam Hussein's government) forced all the ancient Citadel's population to move out (MacFarquhar, 2003). The latter population were Turkish speaking ethnicities basically Turkmens and Chaldeans, the regime then enforced an Arabization policy towards non-Arab ethnicities in the City (Bet-Shlimon, 2019). After evacuating the Citadel, authorities demolished almost all the residential buildings in the existing historical urban fabric, keeping only 50 out of around 800 houses and some monuments (Saatci, 2003), leaving the remaining buildings in vacant fields detached from their original fabric (Figures 1 and 2).

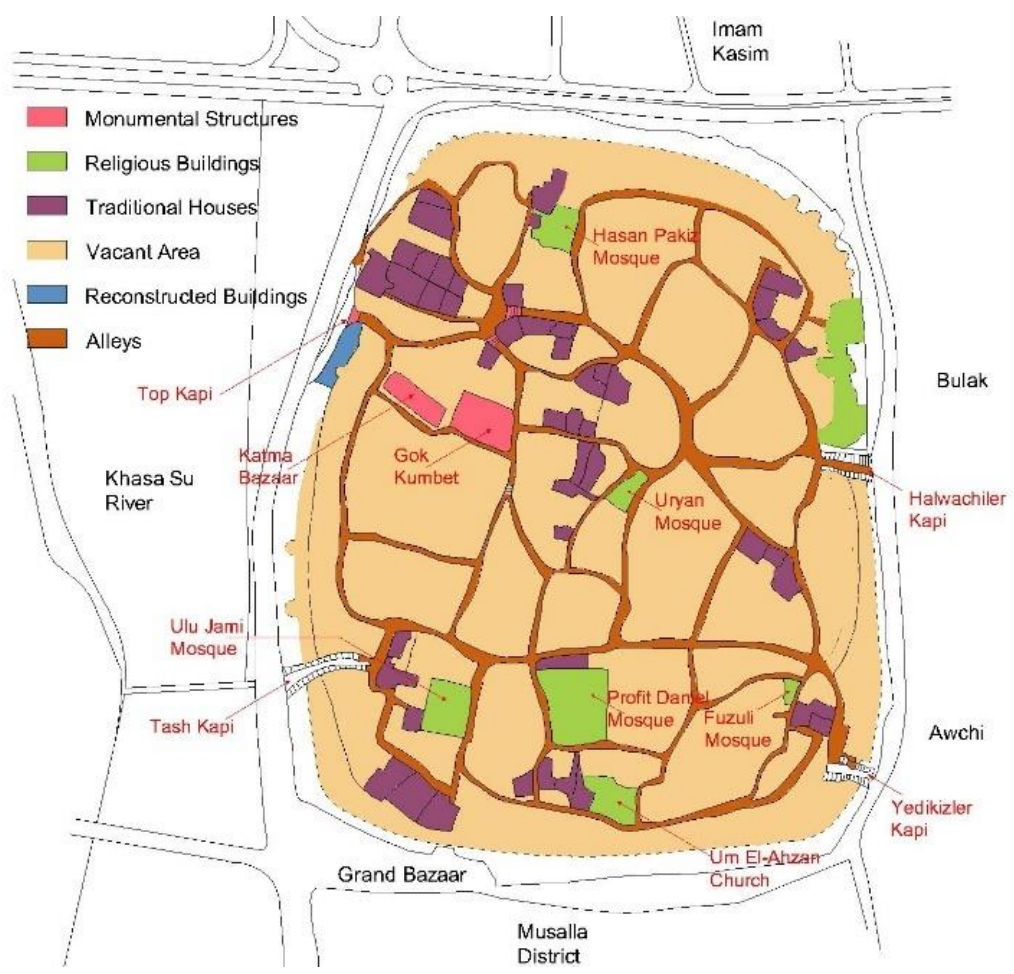


Figure 1 The current land use of Kirkuk Citadel, redrawn from the hand-drawn site plan of the Citadel by Kirkuk Directorate of Antiquities and Heritage (KDAH) (Mustafa Mokhtar's archive)

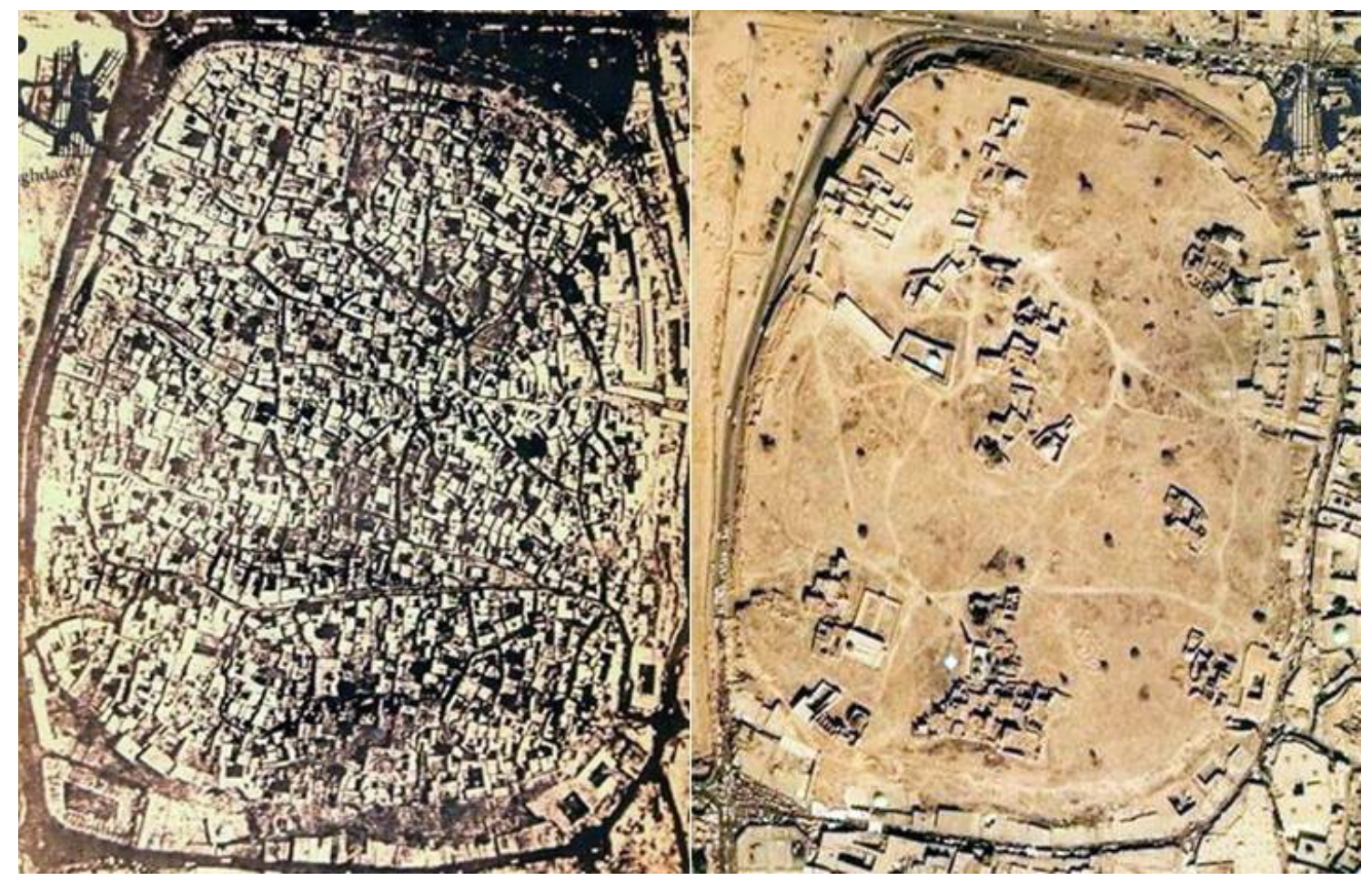

Figure 2 Ariel photos of Kirkuk Citadel, before the destruction (left) and the situation in 2010 (right) (Mokhtar and Korumaz, 2017, p. 130)

Kirkuk Citadel was built above an archaeological tell, where 51 tablets found in 1923, showed that the history of the City goes back to the middle of the second millennium B.C. (Baqer and Safar, 1962). After the Citadel's position as a defensive fortress had ended, the outer walls were disappeared and replaced by residential buildings, which gave the Citadel a civilian character more than a military fortress. Excavations in the year 2000 lead by the Kirkuk Directorate of Antiquity in the northern sides of the Citadel, discovered remains of walls built by thick adobe bricks with semicircular abutments. The topography, climate, construction materials, absence of orthogonal grids, consideration of civil aesthetics and social segregation in Kirkuk Citadel is a clear evidence of being a cultural descent of the ancient Mesopotamian cities, like Erbil Citadel and many others (Oliveira, 2016, p. 54).

\subsubsection{The Cultural Heritage of Kirkuk Citadel}

The Citadel has a semi-rectangular shape with rounded corners, having a dimension of approximately 500x400 meters and nearly 20 meters high above the nearby ground level. There are four gates which allow entrance to the Citadel, Tash Kapi in front of Tash Kopru (stone bridge), Top kapi (canon gate) opening to Khasa Su river side, YediKizler gate and Halwachilar gate both lead to the east side of the Citadel. Only Top Kapi was remained, which was built with stone and traditional gypsum mortar named "Nura". The same building technic was used in most residential buildings in the Citadel. The urban fabric was distributed in three districts which are Hamam, Aghaliq and Meydan (starting from south to north), and Hamam district was divided into two parts, the Christian Hamam and the Muslim Hamam.

Ulu Jami (meaning the great Mosque in Turkish) or Meryem Ana Jami (Virgin Mary Mosque) is the only functioning mosque (beside Profit Daniel Mosque) till this day, every week people from nearby areas gather here for Friday prayer. The mosque has a rectangular plan with a single dome on the west side. Only the base and part of its minaret on the east side of the building has survived. 
This mosque was originally converted from a previous Church, the exact date of its erection is unknown, but it is estimated that it was built after the 12th century (Saatci, 2003).

The other important mosque is Profit Daniel Mosque, containing three tombs inside, which are believed to belong to Jewish rabbis. Although it's called a mosque, it is more like a shrine which is considered divine even by the Muslims, with people visiting it weekly every Saturday. This mosque Page| 317 is converted from a Jewish temple, but neither the date of the conversion nor the date of its erection is known. The part of the building that contains the tombs is covered with twin domes, which is a distinctive character. Furthermore, this mosque has a minaret, nearly 15-meters high, constructed with special curved bricks, embodying the characteristics of the mosque architecture in the 15th century (Saatci, 2003). In the east side of the latter mosque lays the oldest cemetery in the city, the marble inscription over its entrance indicates that it was restored in the year 1665.

Another mosque located in the north-western side of the Citadel known as Hasan Pakiz Mosque was built by the governor of Shahrizor (the state of Kirkuk at that era) Firari Hasan Pasha in the beginning of the 18th century, being originally part of a religious complex, which included a madrasah (Islamic school) (Saatci, 2003, p. 35). The other two mosques are the Uryan and Fuzuli Mosques. Alongside with these Mosques, a ruin of a Church named Um El-Ahzan is located in southern side of the Citadel in Hamam district. All these mosques and the church were built by local stone with traditional gypsum mortar.

There is also a free-standing mausoleum surrounded by newly built arcades, known as GokKumbet or the Blue Dome. The octagonal brick structure of this monument is decorated with brick panels in all of its facades. The inscription on this monument bears the date 1361 A.D. dating back to the Jalairid Sultanate. As a result of extensive repairs in the 1980s, a pyramid shaped roof was added to the top, which was later changed into a dome by another restoration in recent years. It is important to mention that the Mausoleum was once located inside the courtyard of a destroyed traditional house within the old urban fabric. Among the ruins of the Meydan district near Top Kapi gate, there is a small, covered bazaar known as Katma Bazaar or Kilchiler Bazaar. It is composed of two rows of 17 small shops with a covered hallway between them. The Bazaar remained hidden underground till the demolition project in the year 1998, when excavation and restoration projects took place for this building (Saatci, 2003, p. 35).

The other important elements of the heritage assets of Kirkuk Citadel are the traditional houses. As mentioned previously only 50 houses survived from about 800 houses. Similar to the other traditional houses in the region of Kirkuk characterized by particular architectural and typological features, these houses reflect Turkmen ethnicity's way of building in the region. The most obvious feature is the typology of the Dor-Ataba part of the houses, which functions as the modern living room. This part can be seen in almost every traditional house of the Turkmen populated cities and villages in the region. Only a dozen of these houses are restored, the remaining are in very poor condition and deterioration is increasing every passing year.

After nearly 20 years in the destruction of Kırkuk Citadel and with the change in the regime, The Permanent Delegation of Iraq suggested to add Kirkuk Citadel to the tentative list of UNESCO World Heritage, which was approved on 6th of April 2021 (Url-3). The justification of outstanding universal value depends on meeting Criterion iii and iv, and described as follows:

Criterion (iii): Kirkuk Citadel represents a unique testimony to an existing civilization that has not disappeared, as urban monuments, especially the heritage houses inhabited so far, as well as the places of worship in the citadel.

Criterion (iv): The architectural styles on which the architectural features of the citadel were built are unique, and they adopted the construction methods prevailing in Iraq during 
that period, and those architectural styles were preserved through the restoration and preservation work that was carried out in the citadel.

It is also stated that "the historical design of the citadel was preserved through the relationship between the components of the citadel and the citadel is still vibrant and inhabited by the people. The preservation and restoration process is still taking place in the citadel and the use of traditional building materials and archaeological investigations are underway in many parts of the castle, to link existing landmarks to each other and establish a sequence (stratigraphy) for the site's layers".

Although the justifications in the nomination dossier claim that the citadel is still vibrant and inhabited by people, the level of intervention has to be in large scale in order to bring life back to Kirkuk Citadel, as the majority of the area within is vacant and only the monumental buildings are subject to restoration. Currently Turkish Ministry of Culture and Tourism is restoring officers' graveyard next to the Prophet Daniel Mosque and the Gok Kumbet (which was named The Green Dome in the text). Apart from Gok Kumbet, it is seen that Turkish names were changed into Arabic phrases such as Uryan Mosque was put into the text as Al-Aryan Mosque and Topkapi as Bab alToub. These facts bring new areas of discussion about the political intention of the Iraqi State, ensuring social life for Turkmens, who were the real residents of the site and the preservation of tangible and intangible cultural heritage in the Citadel.

\subsubsection{The General Context of the Citadel}

Alongside the heritage assets of Kirkuk Citadel which have been discussed earlier, the other relevant aspects of the context in which the Citadel is situated includes the administrative, legal, political, socio-cultural, economic and climatic environments.

\section{Administrative Aspects}

Kirkuk Citadel and the heritage assets underlying within it, are in the responsibility of "Kirkuk Directorate of Antiquities and Heritage" which is a branch of "Antiquities and Heritage General Authority" in Baghdad within the administration of the "Ministry of Culture, Tourism and Antiquities" (MCTA, 2015). "Kirkuk Directorate of Antiquities and Heritage" which directly administrates the Citadel, coordinates with "Kirkuk Governorate" in mutual projects or any affair concerning the sites within the authority of the Directorate. It should be noted that there are two Mosques (Prophet Danial and Ulu Jami) which are under the administration of the Iraqi "Sunni Endowment Office". The responsibility of securing the Citadel is upon the "Police of Antiquities and Heritage", which is one of the "Iraqi Ministry of Interior's" department. Today there are only four guards securing the whole site of the Citadel (IMI, 2019).

\section{Economic Context}

Usually the financial assets that support projects concerning the Citadel comes from the "Ministry of Culture, Tourism and Antiquities". Recent turbulences and the austerity policy applied in Iraq, significantly reduced the share of the Ministry from the Federal Budget of the Country, as a result, serious conservation or restoration projects for the Citadel never occurred. This kind of dilemma between different governmental establishments directly or indirectly responsible for the Citadel, derives from the long period of dereliction towards the historical site and is not helpful in protecting cultural assets.

\section{Legal Aspects}

As mentioned above, the Iraqi regime during 1998 had forced all the Citadel's population to move out, forcibly expropriating their houses and giving them in return distant land pieces in the City as compensation. Therefore, all the land property in the Citadel nowadays are in the possession of the "Kirkuk Directorate of Antiquities and Heritage". In order to protect and conserve the antiquities and heritage, and organizing excavation and restoration operations, the Iraqi "Supreme 
Judicial Council" legislated the "Antiquities and Heritage Law" numbered 55 for the year 2002 (AlMusawi, 2012). The antiquities and heritage assets should be declared by a decision of the Minister of Culture and the authorities of antiquities and heritage have the right to expropriate the real estates that contain antiquities within it. The law implies severe punishments for various types of intentional damages to the antiquities and heritage assets (Al-Musawi, 2012).

\section{Political and Socio-cultural Environment}

Generally political parties in Kirkuk are distributed ethnically and each party claims the cultural and historical ownership of the City. As Kirkuk Citadel is the major cultural and historical feature of the City, it occasionally became a subject for the ethnical tension. In March 2017, when the previous Governor of Kirkuk decided to raise the flag of Kurdistan Region of Iraq over Kirkuk Citadel, the United Nations Assistance Mission for Iraq (UNAMI) raised concerns about the decision (UNAMI, 2017). Despite being uninhabited, deteriorated and left for decay, many people still visit the Citadel periodically every Friday and Saturday, an old tradition in the City which is still practiced. They gather for the Friday prayer in Ulu Jami and visit Prophet Danial's tomb on Saturdays. Since 2003, the Newroz spring festival is annually celebrated in the Citadel and people from inside and outside Kirkuk also visit the Citadel to explore the historical monuments and the remaining traditional houses of the city. Kirkuk Citadel represents a very important socio-cultural feature in the city for all its inhabitants, and also attracts small number of tourists from other cities in Iraq and rarely foreign tourists.

\subsubsection{Risk Assessment of Kirkuk Citadel}

Within the scope of the study, the 10 agents of deterioration for Kirkuk Citadel are discussed in short and summarized in Table 1, in order to have a comprehensive understanding of the possible risks and their impact on cultural heritage.

The Citadel of Kirkuk has a history of poor interventions during several restoration projects that took place in this historical site, which led to the loss of many ornamental features in the survived buildings. Furthermore, the majority of the survived historical and traditional buildings from the destruction are unused, unlocked and totally susceptible to all kind of physical risks. After the fall of the previous Iraqi regime in 2003 , and the security vacuum in the country accompanied with it, plenty of moveable parts in the remained buildings of the Citadel, like original iron window frames and wooden doors were stolen. In addition to previous criminal acts, a lot of graffiti vandalism could be seen on the walls of the heritage structures. Due to majority of the buildings being disused with no electrical installations or equipment and furniture, fire risks are rare in the Citadel. The few buildings which are in use recently (like Prophet Daniel and Ulu Jami Mosques) are vulnerable to fire incidents. Rainwater is the major agent of deterioration of the historical buildings in the Citadel. About 40 houses from the all 50 remaining traditional houses in the Citadel are ruined, their ceilings partially destroyed and the interior of the houses are exposed to rainwater and all other deterioration agents. Among all kinds of pests, termites have the most effective causes of damage to the historical structures in the Citadel, especially to the wooden doors and window frames. Dust storms are the main pollutants in the region and the most contaminative towards the buildings in the historical site. These storms usually occur during the summer season.

Table 1 Risk agents in Kirkuk Citadel considering the types of occurrence

\begin{tabular}{lll}
\hline & Rare Events & Common Events \\
& \\
\hline Physical Forces & - Destructive interventions \\
& - Collapsing of overloaded ceilings \\
\end{tabular}




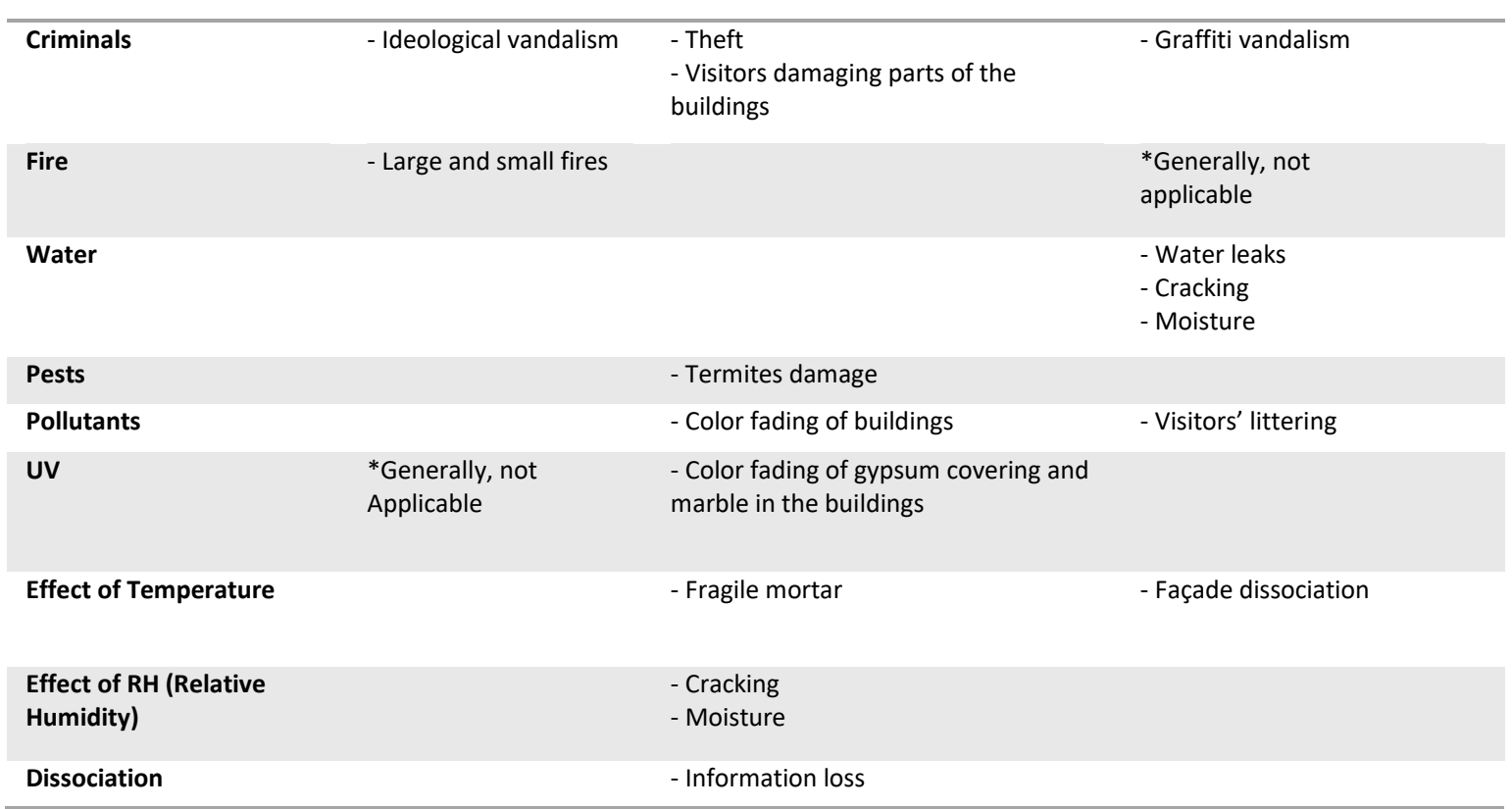

The majority of the buildings in the site have no doors nor glasses in their openings -being looted or damaged-, therefore the interiors are in exposure to all kinds of pollutants. The UV index of sunlight in Kirkuk reaches extreme levels in months like June and July, with level of 11, which causes extensive change in colour to gypsum covering and marble decorative parts of the historical buildings' exterior and interior, colour changes are more explicit in the southern facades. And finally, a lot of inscriptions on the monumental buildings, have been lost by vandalism or other physical effects, which contained information about the monuments that were not documented, resulting in dissociation.

\subsection{The Case of the Old Town of Van}

The old town of Van, located on a plain land is circumscribed with Van Fortress in the north and double city walls in the other directions, which were built in the eleventh century (Uluçam, 2000, p. 21). Although the Castle houses ruins from Urartian Kingdom centred at the Lake Van basin between the ninth and sixth centuries BC, and early Christian temples, the old town of Van was settled much later. Being a prosperous Ottoman town until the beginning of the 20th century because of trade, the town had 243 streets, 5000 dwellings, a military barrack, four markets, a jailhouse, courthouses, pharmacies and inns at the end of the 19th century (Cuinet, 1892, p. 694). The town faced invasion by the Russian army and Armenian gangs which started in 1915 and ended in 1918, resulting in the evacuation of the town and destruction of almost all buildings, and the town has not been settled since then (Öztürk, 2004, p. 53).

\subsubsection{The Cultural Heritage of the Old Town of Van}

There were four gates of the city walls of the old town of Van. Tebriz Gate on the east had two towers on both sides (Evliya Çelebi, 2000, p. 253), on the south walls there were Middle Gate and Pasha Gate, of which Pasha Gate was reconstructed, and on the east there was Port Gate, which was completely destroyed. Apart from the gates there were several religious buildings within the city walls. While Great Mosque of Van (14th Century) and Red Minaret Mosque (13th Century) were built prior to the Ottoman Period (Güzeloğlu, 1995; Kuban, 2002; Saban Ökesli and Akar, 2012, pp. 41-43), they both show unique features of the traditional construction techniques and the materials. The Ottoman mosques that have survived are Kaya Çelebi Mosque (16th-17th century) (Güzeloğlu, 1995, pp. 36-37; Uluçam, 2000, pp. 51-54), Hüsrev Pasha Complex (16th century) (Uluçam, 2000, pp. 38-48), Kethüda Ahmet Mosque (19th century) (Uluçam, 2000, pp. 59-60), Horhor Mosque (17th century) (Uluçam, 2000, pp. 55-58) and Beylerbeyi Mustafa Pasha Mosque (17th century) (Uluçam, 2000, p. 58). Although all of them were greatly damaged as a result of the 
destruction in early 20th century and earthquakes that occurred in the area in later years, Kaya Çelebi Mosque and Hüsrev Pasha Complex were reconstructed in early 21st century aiming to reflect the Ottoman life in the old town of Van (Figures 3 and 4).

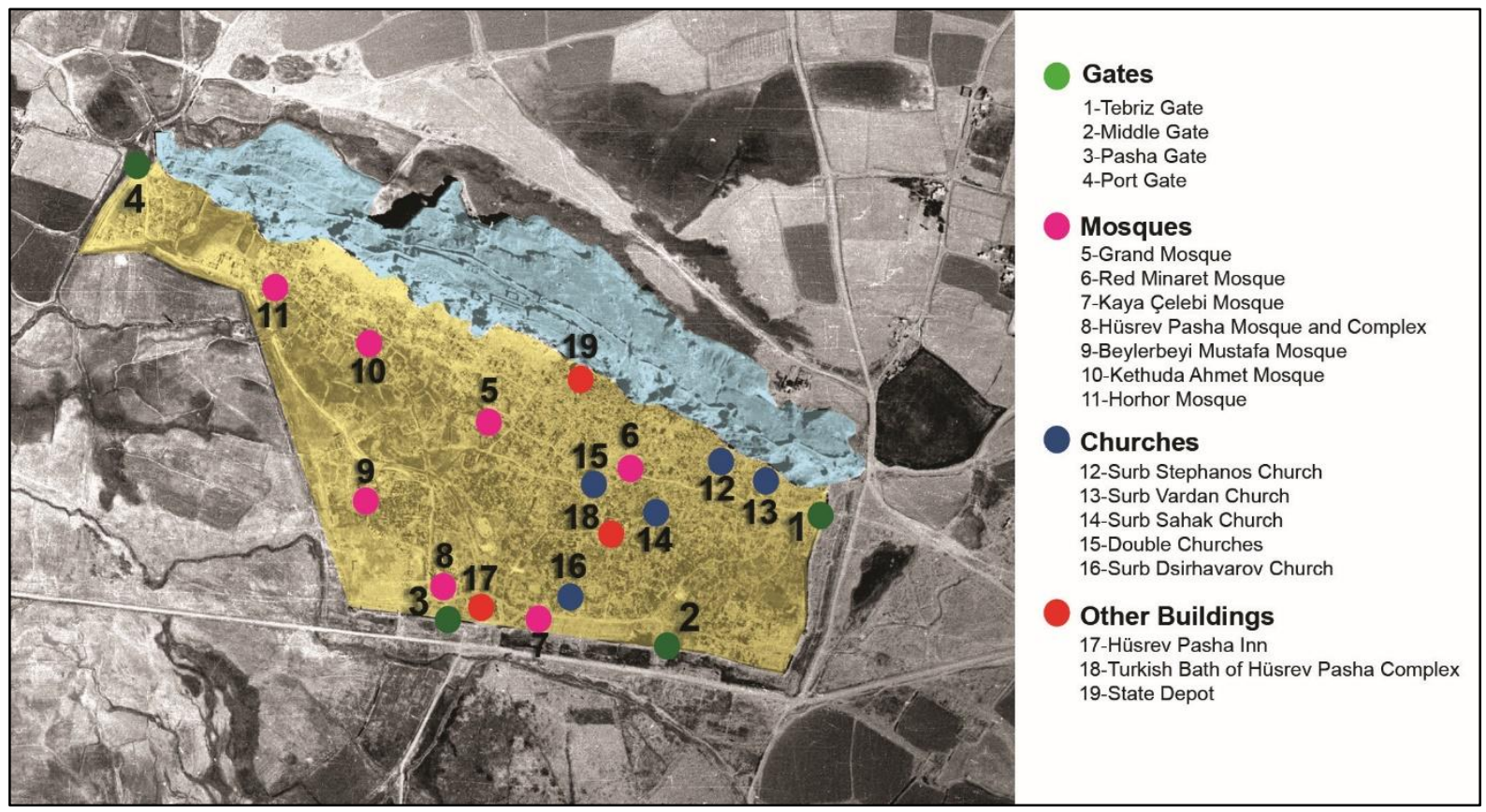

Figure 3 Historic monuments in the Old Town of Van (redrawn form Saban Ökesli and Akar, 2012, p. 36)
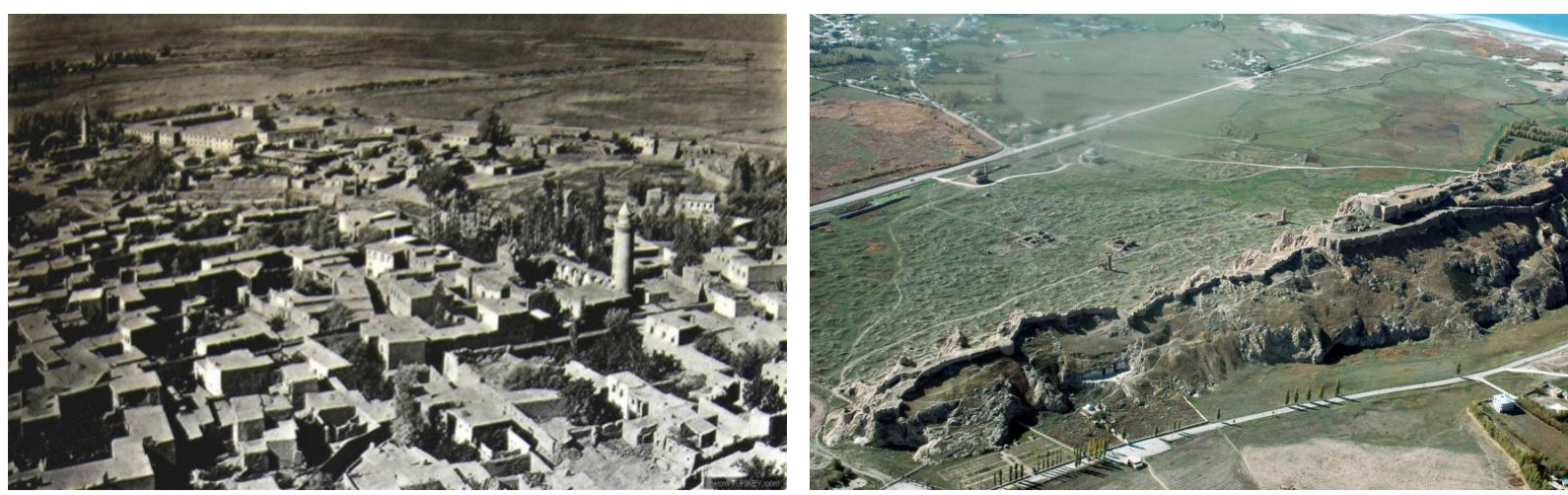

Figure 4 The Old Town of Van before 1915 (left) (Saban Ökesli and Akar, 2012, p. 29) and the situation in 2012 (right) (Saban Ökesli and Akar, 2012, p. 17)

There are also ruins of churches within the walls of the town, although construction dates are unknown, which are Surb Stephanos Church (Uluçam, 2000, p. 67), Surb Vardan Church (Uluçam, 2000, p. 65), Surb Sahak Church (Uluçam, 2000, p. 61), Surb Dsirhavarov Church (Uluçam, 2000, p. 68) and Double Churches (Surb Paulos and Surb Petros) (Uluçam, 2000, p. 63; Güzeloğlu, 1995, p. 39). Amongst them Surb Dsirhavarov Church is recently restored, however the building is under risk of flooding (Saban Ökesli and Akar, 2012, p. 55). Apart from these buildings there are also ruins of Hüsrev Pasha Inn (16th century), Turkish Bath of Hüsrev Pasha Complex (16th century) and State Depot (18th century) (Uluçam, 2000, pp. 68-69) within the walls of the Old Town of Van.

The Old Town of Van was added to the tentative list of UNESCO World Heritage in 1986, however the application was renewed and the Permanent Delegation of Turkey nominated Tushpa/Van Fortress, the Mound and the Old City of Van to the tentative list of UNESCO World Heritage, which was approved on 13th of April 2016 (Url-4). The justification of outstanding universal value depends on meeting Criterion ii, iii, iv and vi, and the justification for the Old Town of Van were described as follows: 
Criterion (ii): Van Fortress and surroundings as shaped by the Urartian architects proved to be a convenient habitat for future generations. The rock architecture, for example, was fully exploited by the Ottomans and it was one of the largest castles of the empire in Anatolia. The fact that Persian, Parthian, Sassanian, Christian and Ottoman remains are visible in the site makes it unique in cultural continuity and legacy. Besides all these, it is the single most important centre that Ottoman urban fabric along with that of Urartu is observed.

Criterion(iii): The Kingdom of Urartu, with its political structure, institutions, architecture and other cultural remains, was one of the most developed state structures in the first millennium $B C$ in Anatolia. Representing all the characteristics of the Kingdom of Urartu, the capital Tushpa/Van Fortress bears exceptional testimony to this disappeared civilization. Along with other cultural remains, the site has the richest and longest collection of Urartian inscriptions, making it the most important source for the reconstruction of the Urartian history. Just as it was a witness to the foundation of the Urartian Kingdom, the Lower settlement of Tushpa inevitably contains important archaeological information for the decline and the new comers arrived in the aftermath.

Criterion (iv): Royal rock tombs, monumental open air sanctuaries and palaces are the most prominent architectural features of the capital, which is a unique and still-standing example of a citadel. Every corner of the outcrop, which is by itself a monument, was utilized by the Urartian architects. Monumental rock-cut royal tombs and niches with accompanying inscriptions make the site the most distinctive settlement of the region in the first millennium $B C$. The royal tombs in particular have no parallels in Mesopotamia and Anatolia in that period.

Criterion(vi): Until its abandonment due to the heavy damage inflicted by the events of 1915, the Old City of Van was home to many religious and ethnic groups for 800 years allowing them to leave their unique marks of material culture. This multiculturalism, on the basis of mutual respect, is evident in religious and civilian architecture.

The justifications stated in the nomination dossier emphasizes the importance of the Urartian civilization, and while defining the significance of the Old Town of Van, the prominent justifications are being an example of the Ottoman urban fabric, which was destroyed more than 100 years ago and multiculturalism which is argued to be evident in religious and civilian architecture. The truth is that only two mosques and a chapel were restored in the Town, which do not serve to any residents as there is no settlement within the city walls. The other monumental buildings are in ruins and none of the residential buildings had survived. Therefore, these facts bring new discussions such as considering the size of the Old Town of Van, and that there is no population living in it, how beneficial is the restoration aiming the reuse of some of the monumental buildings and how the conservation plan for the Old Town of Van can be useful for promoting life in the Town.

\subsubsection{The General Context of The Old Town of Van}

The general context of the Old Town of Van is explained below under the same topics as Kirkuk Citadel.

\section{Administrative Aspects}

As the Old Town of Van is abandoned for more than 100 years ago, and there are mostly ruins of heritage assets within the old town, the land is under the responsibility of the State of Turkish Republic.

\section{Economic Context}

Having an area of approximately 45 hectares, the restoration or reconstruction of the cultural heritage within the city walls and re-establishing the Ottoman urban fabric in the Old Town of Van is not viable financially, unless an international consensus is provided. 


\section{Legal Aspects}

The cultural heritage in Turkey are protected according to the provisions of The Law Concerning the Protection of Cultural and Natural Assets numbered 2863, adopted in 1983 and relevant regulations developed since then. There is also a National Inventory for Cultural Heritage, and the Old Town of Van was added to the list in 1979 as a First-Degree Archaeological Site, which has to be protected as intact as possible (Saban Ökesli and Akar, 2012, p. 10).

\section{Political and Socio-cultural Environment}

As the new settlement of the city of Van following the destruction of the old town within walls was moved towards northeast, there is no intention of settling back within the city walls. However, the Old Town of Van and the Van Castle surrounding the northern border having remains from Urartians and Ottomans and is a popular destination for tourists especially because of the view from the castle towards the plain land and the Lake of Van. Following the preparation of conservation plan for the site in 2012, the Old Town of Van and its close surroundings were restricted for construction activities.

\subsubsection{Risk Assessment of the Old Town of Van}

The city of Van has been subject to earthquakes throughout history, and it is still affecting the area. The last earthquake occurred in 2011, resulted in the destruction of the restored mosques within the Old Town of Van. Touristic activities and having no control of tourists bring about problems of security and vandalism to the cultural heritage within the area. As the land within the city walls is empty and too large to control, growing plants are under the threat of fire which cause risk to the remains of monumental buildings (Table 2).

The major natural problem is the high level of groundwater which could not be drained especially in the western part of the old town, adjacent to the Lake of Van. As the main material of construction was adobe (mud brick) within the Old Town of Van, especially for residential buildings, heavy rains for more than 100 years as well as the groundwater, combined with the earthquakes resulted in the extinction of the built environment and the land currently is comprised of small hills, reflecting the presence of houses once in the area. In addition, UV and effect of temperature weaken the survived adobe structures. Pests, pollutants and effect of RV are generally not applicable in the area, however visitors' littering is a problem both for the perception of the area and also because of creating risk for fire.

Table 2 Risk agents in the Old Town of Van considering the types of occurrence

\begin{tabular}{|c|c|c|}
\hline Rare Events & Common Events & Cumulative Processes \\
\hline Physical Forces & $\begin{array}{l}\text { - Earthquakes } \\
\text { - Collapsing of restored } \\
\text { monuments }\end{array}$ & \\
\hline Criminals & $\begin{array}{l}\text { - Visitors damaging parts of the } \\
\text { buildings }\end{array}$ & - Graffiti vandalism \\
\hline Fire & $\begin{array}{l}\text { - Large and small fires in the } \\
\text { open land }\end{array}$ & $\begin{array}{l}\text { *Generally, not } \\
\text { Applicable }\end{array}$ \\
\hline Water & & $\begin{array}{l}\text { - Moisture } \\
\text { - The high level of } \\
\text { groundwater because of } \\
\text { the lake }\end{array}$ \\
\hline Pests & $\begin{array}{l}\text { *Generally, not } \\
\text { Applicable }\end{array}$ & \\
\hline Pollutants & $\begin{array}{l}\text { *Generally, not } \\
\text { Applicable }\end{array}$ & - Visitors' littering \\
\hline
\end{tabular}




\begin{tabular}{|c|c|c|c|}
\hline UV & $\begin{array}{l}\text { *Generally, not } \\
\text { Applicable }\end{array}$ & Fragile mud plaster & Loss in the material \\
\hline $\begin{array}{l}\text { Effect of } \\
\text { Temperature }\end{array}$ & & Fragile adobe structure & $\begin{array}{l}\text { Loss in the material and } \\
\text { demolition of the } \\
\text { structures }\end{array}$ \\
\hline $\begin{array}{l}\text { Effect of RH } \\
\text { (Relative } \\
\text { Humidity) }\end{array}$ & & $\begin{array}{l}\text { *Generally, not } \\
\text { Applicable }\end{array}$ & \\
\hline Dissociation & & - Information loss & \\
\hline
\end{tabular}

\section{Conclusions}

Aiming to raise the questions on how to manage change in the intentionally destroyed historic settlements and how to strengthen resilience in conflict-affected areas, this study examined Kirkuk Citadel and the Old Town of Van, in order to discuss challenges of post-conflict destruction. It is ascertained as a result of the study that the size of the historic settlement, the scale of destruction and the time passed after the destruction are major determinants for the level of intervention. Although the destruction in both case studies is grand in scale, because of covering a smaller area restoration and reconstruction projects developed for Kirkuk Citadel might be effective once they are implemented to re-establish the urban fabric. At the same time, the fact that the efforts to protect the destroyed Kirkuk Citadel started approximately 20 years after the demolition, ensures that the ties of the inhabitants with the site and cultural heritage are re-established before they break. However, in the case of the Old Town of Van, reconstruction of three religious buildings has had no significant improvement in the area because of the size of the Town. In addition, the beginning of the interventions for conservation in the Old Town of Van about a century later, as well as the relocation of the urban settlement, resulted in the rupture of the tangible and intangible ties of the residents with the site. In this case, it is necessary to differentiate the methods, models and conservation scenarios to be followed for strengthening the resilience of cultural heritage that have been similarly destroyed in line with the dynamics of the area.

Furthermore, lack of documentation is another major problem, as only some of the monumental buildings, which constitute only a minor part of the built fabric were recorded. This fact brings about a primary problem, meaning that it is impossible to re-establish the original urban fabric and a major question, is it viable to promote resilience in the areas where physical structure cannot be put back again.

Considering the nomination of both heritage sites to the tentative list of UNESCO World Heritage, it can be argued that ruins of the monumental buildings were seen as a starting point to attract international recognition and a step to raise the potential of the sites for investment. However, does the existing national and international legislation and the know-how really give the opportunity to develop strategies and long-term plans for the recovery of historic settlements intentionally destroyed as a result of armed conflict? Or do we need new and innovative ways of managing such areas, not necessarily focusing on recovering the whole of the area and reconstructing the urban fabric which is not viable because of the level of destruction?

This brings the importance of the involvement of the community, fundamental spiritual and psycho-social support and the sense of belonging to communities. The study revealed that although the level of destruction is grand, cultural and social life can survive and cultural rituals can continue if an even small part of the community keeps living in the area. It can be argued that only total extinction of life in a historic settlement results in the absence of cultural life and sense of belonging, as even the recovery is intended it might take generations to implement, which might result in the loss of traditional knowledge. 


\section{References}

Al-Musawi, N. O. (2012). Criminal protection of heritage in Iraqi law. https://www.hjc.iq/view.1681/. Retrieved November 09, 2021.

Baqer, T., \& Safar, F. (1965). A guide to the homes of antiquities and civilization. المرشد الى مواطن الأثار والحضارة..

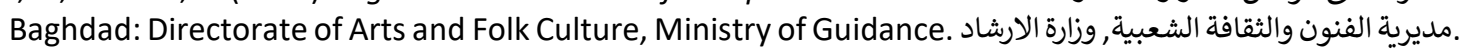

Bet-Shlimon, A. (2019). City of Black Gold; Oil, Ethnicity, and the Making of Modern Kirkuk. Stanford: Stanford University Press. ISBN 9781503609143 (e-book).

Boylan, P. J. (1993). Review of the Convention for the Protection of Cultural property in the Event of Armed Conflict (The Hague Convention of 1954). London: UNESCO.

Brown Scott, J. (1920). The Proceedings of The Hague Peace Conferences. New York: Oxford University Press. Chadra, N. (2001). Protection of Cultural Property During Armed Conflict: Recent Developments. ISIL Yearbook of International Humanitarian and Refugee Law, ISILYBIHRL 12 (http://www.worldlii.org /int/journals/ISILYBIHRL/2001/12.html \#Footnote13), Retrieved November 10, 2021.

Cuinet, V. (1892). La Turquie D’Asie, Géographie Administrative Statistique Descriptive et Raisonnée De Chaque Province De L'Asie Mineure. Tome I-II. Paris: Ernest Leroux Éditeur.

Evliya Çelebi (2000). Seyahatname. Cilt III-IV. İstanbul: Üçdal Neşriyat.

Güzeloğlu, S. (1995). Tanrı Haldi'nin Başkenti-Van ve Çevresine Tarihi ve Arkeolojik Bir Bakış. İstanbul: Biber Tanıtım.

Higgins, A. P. (1909). The Hague Peace Conferences and other International Conferences Concerning the Laws and Usages of War. Cambridge: Cambridge University Press.

ICCROM (2016). A Guide to Risk Management of Cultural Heritage. htpps://www.iccrom.org (Retrieved November 09, 2021).

IMI. (2019). Police of Antiquities and Heritage. The Iraqi Ministry of Interior IMI Retrieved November 02, 2021 https://moi.gov.iq/index.php?name=Pages\&op= page\&pid=158.

IPCC. (2012). Managing the Risks of Extreme Events and Disasters to Advance Climate Change Adaptation. A Special Report of Working Groups I and II of the Intergovernmental Panel on Climate Change. [Field, C.B., V. Barros, T.F. Stocker, D. Qin, D.J. Dokken, K.L. Ebi, M.D. Mastrandrea, K.J. Mach, G.-K. Plattner, S.K. Allen, M. Tignor, and P.M. Midgley (eds.)]. Cambridge: Cambridge University Press. 582 pp. Available

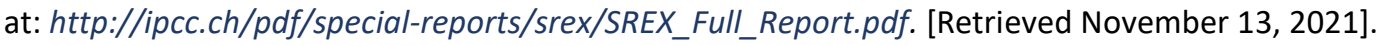

Keane, D. (2004). The Failure to Protect Cultural Property in Wartime. DePaul Journal of Art, Technology \& Intellectual Property Law, Vol. 14, Issue 1, Special Section: Art and War, pp. 1-38.

Kuban, D (2002). Selçuklu Çağında Anadolu Sanatı, İstanbul: Yapı Kredi Yayınları 1567.

Lostal, M. (2017). Two Wrong Ways of Thinking about the Legal Protection of Cultural Property in Armed Conflict, In M. Lostal Ed., International Cultural Heritage Law in Armed Conflict Case Studies of Syria, Libya, Mali, the Invasion of Iraq, and the Buddhas of Bamiyan, pp. 18-47. Cambridge: Cambridge University Press.

MacFarquhar, N. (2003). The Struggle for Iraq: The Reconstruction; Divided by Hussein, an Oil Town in Northern Iraq in Slow to Hal. The New York Times, 28 September 2003, p.19.

MCTA. (2015). Merging the Ministry of Tourism and Antiquities with the Ministry of Culture. Ministry of Culture, Tourism and Antiquities MCTA Retrieved November 15, 2021, http://mocul.gov.iq /index.php?name=News\&file=article\&sid=5014.

Middle East Institute, Asia Society, and the Antiquities Coalition, Culture under Threat: Recommendations for the U.S. Government. April 2016. Retrieved November 01, 2021, http://www. academia. edu/30873427/Culture_Under_Threat_Recommendations_for_the_U.S_Government.

Mokhtar, M. and Korumaz, M. (2017). The Adaptive Reuse of Kirkuk Citadel, ICONARP International Journal of Architecture \& Planning, Volume 5, Special Issue, pp: 117-140.

Murthy, M. (2013). Heritage and Resilience-Issues and Opportunities for Reducing Risks. Genova: Global Platform for Disaster Risk Reduction.

Oliveira, V. (2016). Urban morphology: an introduction to the study of the physical form of cities: Springer (ebook) (retrieved November 09, 2021, https://link.springer.com/book/10.1007/978-3-319-32083-0.

Öztürk, Ş. (2004). Eski Van Şehri, Mimarlık, Sayı 317, pp. 52-54.

Saatci, S. (2003). Kerkuk Evleri (English version: The Urban Fabric and Traditional Houses of Kirkuk, 2007). İstanbul: Kerkuk Vakfı.

Saban Ökesli, D. ve Akar, T. (2012). Van Kalesi ve Çevresi Koruma Amaçlı Imar Planı Araştırması-Mimari Rapor (Research for Conservation Plan of Van Castle and its Surroundings-Architectural Report), Unpublished report submitted to Taha Orhan Planlama A.Ş. 
Uluçam, A. (2000). Ortaçağ ve Sonrasında Van Gölü Çevresi Mimarlığı I Van, Ankara: Kültür Bakanlığı Yayınları, Sanat Eserleri Dizisi 288.

UNAMI. (2017). The United Nations Assistance Mission for Iraq UNAMI Concerned by Raising Kurdistan Flag in Kirkuk, Cautions Against Unilateral Steps. 21 March 2017. Retrieved November 15, 2021, http://www.uniraq.org/index. php?option=com_k2\&view=item\&id=7001:unami-concerned-by-raisingkurdistan-flag-in-kirkuk-cautions-against-unilateral-steps\&ltemid=605\&lang=en.

UNESCO (2003). Declaration Concerning the Intentional Destruction of Cultural Heritage. Page | 326 https://international-review.icrc.org (Retrieved November 09, 2021).

UNESCO (2015). Reinforcement of UNESCO's Action for the Protection of Culture and the Promotion of Cultural Pluralism in the Event of Armed Conflict. https://en.unesco.org/heritage-at-risk/strategyculture-armed-conflict (Retrieved November 09, 2021).

Weiss T. G. And Connelly, N. (2017). Cultural Cleansing and Mass Atrocities-Protecting Cultural Heritage in Armed Conflict Zones, J. Paul Getty Trust Occasional Papers in Cultural Heritage Policy, Number 1, Los Angeles: J. Paul Getty Trust.

Url-1: Retrieved November 09, 2021, http://www.unesco.org/new/en/culture /themes/armed-conflict-andheritage/convention-and-protocols/1954-hague-convention/.

Url-2: Retrieved November 09, 2021, http://www.unesco.org.

Url-3: Retrieved November 08, 2021, https://whc.unesco.org/en/tentativelists/6522/.

Url-4: Retrieved November 08, 2021, https://whc.unesco.org/en/tentativelists/6114/.

\section{Resume}

Fazilet Duygu Saban is an architect graduated from Mimar Sinan Fine Arts University. She received her M.Sc. degree at Çukurova University and Ph.D. degree at University College London, Bartlett School of Planning. She is currently working at Çukurova University, Faculty of Architecture, Department of Architecture and her research areas focus on history of architecture, urban history, urban conservation and architectural heritage.

Mustafa Mokhtar is an assistant lecturer in Department of Architectural Engineering at Cihan University and a Ph.D. candidate at Çukurova University. His work focuses on the conservation of cultural heritage and the new construction within historical contexts. Kirkuk, the city which he lives in and the diverse regional cultures are the most research subjects he interested in.

Tuba Akar is graduated from the Department of Architecture at Çukurova University (B.Arch 1997), received her M.Sc. (2002) and Ph.D degrees at Middle East Technical University in Restoration Graduate Program in the Faculty of Architecture. She worked as a research assistant at the same university during her graduate education. Since September 2009, she has been working at Mersin University, Department of Architecture. Areas of study and interests; urban and architectural conservation, waqf institution and conservation, historical sources in conservation, Ottoman period commercial buildings and historical commercial centers. 